\title{
A Review of the Indian Automobile Manufacturing Sector
}

\author{
Mohd. Asif Gandhi ${ }^{1}$ \\ ${ }^{1}$ Department of Mechanical Engineering, Anjumain-I-Islam's Kalsekar Technical Campus, School of \\ Engineering and Technology, Mumbai University, India
}

\begin{abstract}
This paper summarizes the various automobile manufacturing firms in India along with their plants, if any, and along with their geographical locations. Also this paper gives a classification of the various classes of automobiles manufactured in India along with the state wise, location wise, firm wise listing. This type of information is typically very useful for researchers in carrying out their research work in the automobile manufacturing sector of India. It can be used as a ready reference by managers for conducting various kinds of surveys of the automobile manufacturing sector of India, for example researchers doing research in the area of supply chain management; or green supply chain management may like to have an exhaustive listing in the way it is illustrated and interpreted in this paper.
\end{abstract}

Keywords: Automobile, Indian, Manufacturing Sector, Plants, Review

\section{Introduction}

This paper addresses an important issue pertaining to researchers in the field of automobile manufacturing. An exhaustive listing of the various automobile manufacturing firms and their plants as shown in this paper is not available in a convenient form. This paper lists the various classifications of automobile manufacturing sector of India like class wise, state wise, location wise, firm wise which makes it convenient for researchers and managers to refer and extract information that they want without reinventing the wheel.

\section{Firm Wise Distribution of Indian Automobile Manufacturing Plants}

There are 58 automobile manufacturing firms in India spread over 97 manufacturing plants in all [1], [2]. The firm wise distribution of plants is as shown in Table 1 .

Table 1. Firm wise distribution of automobile manufacturing plants in India

\begin{tabular}{|l|c|c|}
\hline \multicolumn{1}{|c|}{ Manufacturing firm } & No. of plants & \% of total plants \\
\hline Ashok Leyland Limited & 1 & 1.03 \\
\hline Asia Motor Works AMW & 1 & 1.03 \\
\hline Audi India & 1 & 1.03 \\
\hline BharatBenz & 1 & 1.03 \\
\hline BMW India & 1 & 1.03 \\
\hline CASE NEW HOLLAND INDIA & 1 & 1.03 \\
\hline Caterpillar India Pvt. Ltd. & 1 & 1.03 \\
\hline CNH Industrial & 1 & 1.03 \\
\hline Daimler & 1 & 1.03 \\
\hline Deccan Auto & 1 & 1.03 \\
\hline Eicher Motors & 1 & 1.03 \\
\hline Fiat India Automobiles Limited & 1 & 1.03 \\
\hline Ford India Private Limited & 1 & 1.03 \\
\hline Ford motors & 1 & 1.03 \\
\hline Harley-Davidson India & 1 & 1.03 \\
\hline Honda Cars India & 1 & 1.03 \\
\hline Honda Motorcycles & 1 & 1.03 \\
\hline Hyundai Motor India Limited & 1 & 1.03 \\
\hline International Cars \& Motors Limited & 1 & 1.03 \\
\hline International Tractors Limited (Sonalika Group) & 1 & 1.03 \\
\hline Isuzu Motors & 1 & 1.03 \\
\hline Jaguar \& Land Rover [41] & 1 & 1.03 \\
\hline Kamaz Vectra Motors Limited & 1 & 1.03 \\
\hline Kinetic Engineering Limited & 1 & 1.03 \\
\hline Mahindra Navistar & 1 & 1.03 \\
\hline Mahindra REVA Electric Vehicles & 1 & 1.03 \\
\hline MAN Force Trucks Private Limited & 1 & 1.03 \\
\hline Mercedes-Benz India & 1 & 1.03 \\
\hline Mitsubishi & & 1.03 \\
\hline New Holland Agriculture / CHN & 1 & 1.03 \\
\hline Nissan Motor India Private Limited & 1 & \\
\hline & 1 & 1 \\
\hline
\end{tabular}


A Review of the Indian Automobile Manufacturing Sector

\begin{tabular}{|l|c|c|}
\hline \multicolumn{1}{|c|}{ Manufacturing firm } & No. of plants & \% of total plants \\
\hline Piaggio \& C. SpA & 1 & 1.03 \\
\hline Renault India Private Limited & 1 & 1.03 \\
\hline Royal Enfield & 1 & 1.03 \\
\hline Scania Commercial Vehicles India Private Limited & 1 & 1.03 \\
\hline Skoda Auto India Private Limited & 1 & 1.03 \\
\hline SML Isuzu Limited & 1 & 1.03 \\
\hline Suzuki & 1 & 1.03 \\
\hline Volkswagen India Private Limited & 1 & 1.03 \\
\hline Volvo Buses India Private Limited & 1 & 1.03 \\
\hline Yamaha & 1 & 1.03 \\
\hline Bajaj Auto & 2 & 2.06 \\
\hline Force Motors & 2 & 2.06 \\
\hline General Motors India Private Limited & 2 & 2.06 \\
\hline Hero MotoCorp & 2 & 2.06 \\
\hline Honda & 2 & 2.06 \\
\hline India Yamaha Motor Private Limited & 2 & 2.06 \\
\hline Maruti Suzuki & 2 & 2.06 \\
\hline Premier Automobiles Limited & 2 & 2.06 \\
\hline Toyota Kirloskar Motor Private Limited & 2 & 2.06 \\
\hline Hero Honda & 3 & 3.09 \\
\hline Hindustan Motors & 3 & 3.09 \\
\hline Ashok Leyland & 4 & 4.12 \\
\hline TVS Motors & 4 & 4.12 \\
\hline Honda Siel Cars India & 5 & 5.15 \\
\hline TAFE Tractors & 6 & 6.19 \\
\hline Tata Motors & $\mathbf{9 7}$ & 6.19 \\
\hline Mahindra \& Mahindra & $\mathbf{2}$ & 7.22 \\
\hline Total automobile manufacturing plants in India & $\mathbf{1 0 0 . 0 0}$ \\
\hline
\end{tabular}

The firm wise distribution of Indian automobile manufacturing plants is shown graphically in Fig. 1 below.

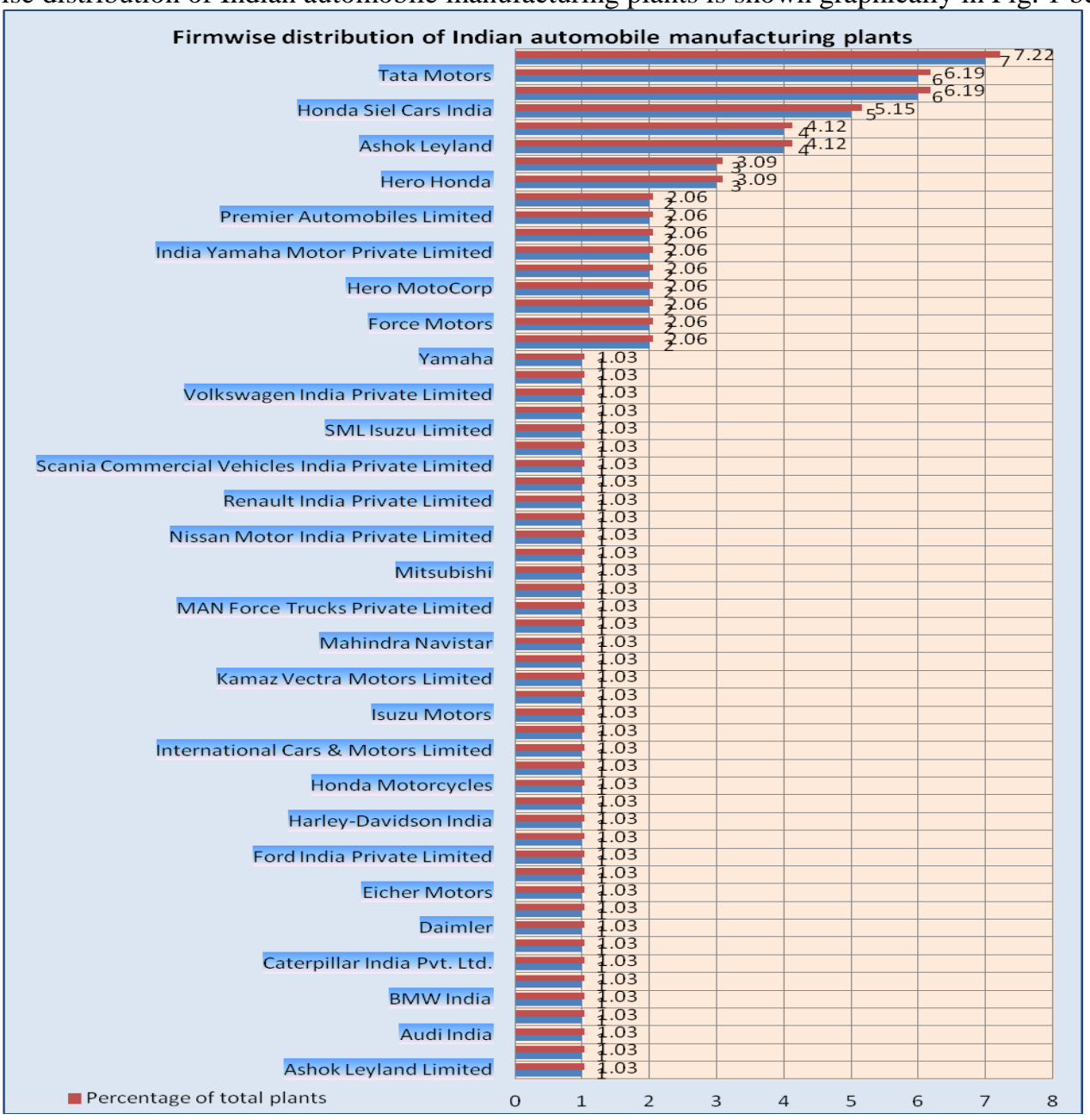

Figure 1. Graphical illustration showing firm wise distribution of Indian automobile manufacturing plants 
From Fig. 1 and Table 1 it is evident that the Indian automobile manufacturing firms in the descending order of the number of plants they have is Tata Motors, Honda Siel Cars India, Ashok Leyland, Hero Honda, Premier Automobiles Limited, India Yamaha Motor Private Limited, Hero MotoCorp, Force Motors, Yamaha, Volkswagen India Private Limited, SML Isuzu Limited, Scania Commercial Vehicles India Private Limited, Renault India Private Limited, Nissan Motor India Private Limited, Mitsubishi, MAN Force Trucks Private Limited, Mahindra Navistar, Kamaz Vectra Motors Limited, Isuzu Motors, International Cars and Motors Limited, Honda Motorcycles, Harley-Davidson India, Ford India Private Limited, Eicher Motors, Daimler, Caterpillar India Pvt. Limited, BMW India, Audi India, Ashok Leyland Limited. So on one end of the spectrum Tata Motors is the firm with the largest number of automobile manufacturing plants and on the other end of the spectrum Ashok Leyland Limited has the smallest number of automobile manufacturing plants.

\section{Class Wise Distribution Of Indian Automobile Manufacturing Plants}

There are 7 broad classes of automobiles manufactured in India collectively by all the 58 automobile manufacturing firms through their 97 plants. These broad classes of vehicles are Excavators, back hoe loaders; Agriculture Equipment, combines; Bus Manufacturing Plant; Farm Tractors; Two wheelers; Passenger vehicles; and Commercial vehicles [1], [2]. Table 2 shows class wise distribution of the Indian automobile manufacturing plants in numbers and also in terms of percentage of the total number of Indian automobile manufacturing plants.

Table 2. Class wise distribution of Indian automobile manufacturing plants

\begin{tabular}{|c|c|c|c|}
\hline Sr. No. & Class of automobile & No. of automobile manufacturing plants & \% of automobile manufacturing plants \\
\hline 1 & Excavators, back hoe loaders. & 1 & 1.04 \\
\hline 2 & Agriculture equipment, combines & 2 & 2.08 \\
\hline 3 & Bus Manufacturing Plant & 2 & 2.08 \\
\hline 4 & Farm Tractors & 5 & 5.21 \\
\hline 5 & Two wheelers & 21 & 21.88 \\
\hline 6 & Passenger vehicles & 30 & 31.25 \\
\hline 7 & Commercial vehicles & 35 & 36.46 \\
\hline
\end{tabular}

Fig. 2 shows graphically the class wise distribution of the Indian automobile manufacturing plants.

\section{Manufacturing plants of different classes of automobiles in India}

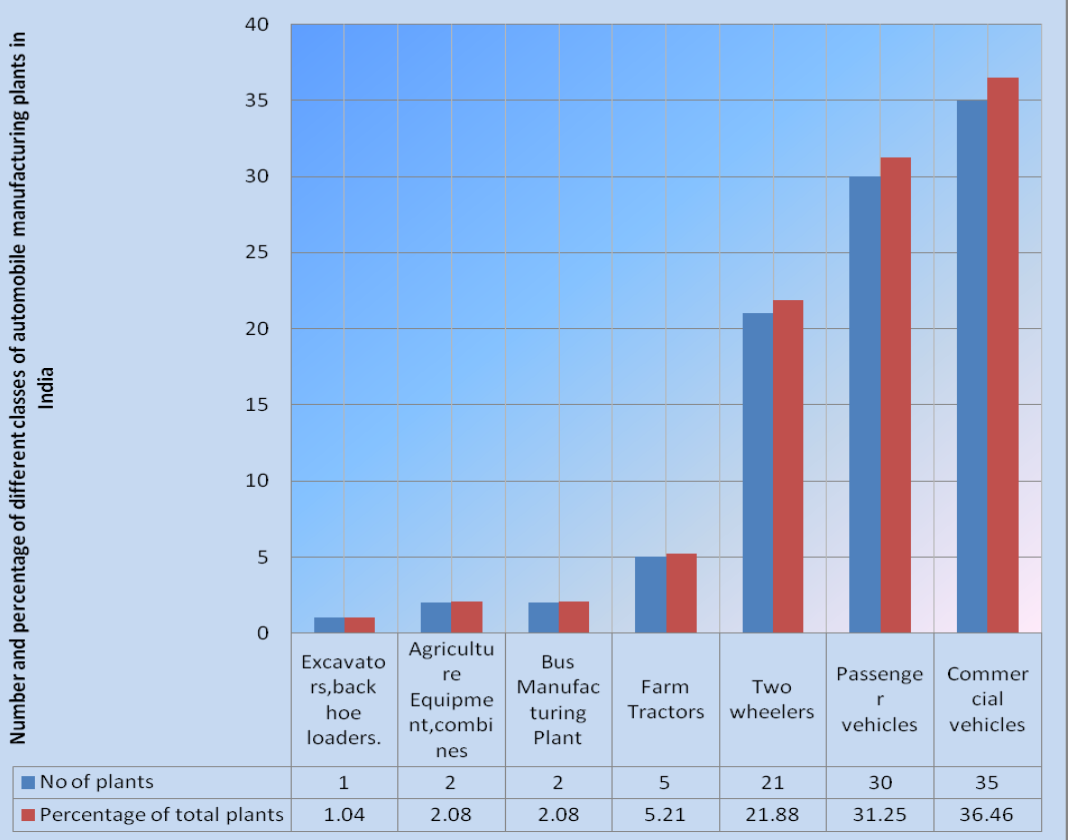

Figure 2. Class wise distribution of the Indian automobile manufacturing plants

From Fig. 2 and Table 2 it is evident that commercial vehicles are manufactured in maximum number of plants in India followed by passenger vehicles followed by two wheelers followed by farm tractors followed by bus manufacturing plants followed by agriculture equipment and combines plants followed by excavators and backhoe loaders plants. 


\section{State Wise Distribution of Indian Automobile Manufacturing Plants}

There are 15 states in India which have automobile manufacturing plants of Indian firms. The names of these Indian states in alphabetical order are Andhra Pradesh, Gujarat, Haryana, Himachal Pradesh, Jharkhand, Karnataka, Madhya Pradesh, Maharashtra, Punjab, Rajasthan, Tamil Nadu, Telangana, Uttar Pradesh, Uttarakhand, West Bengal [1], [2]. Table 3 shows the fifteen states of India in the descending order of the number of Indian automobile manufacturing plants.

Table 3. State wise distribution of Indian automobile manufacturing plants

\begin{tabular}{|c|c|c|c|}
\hline Sr. No. & Name of Indian State & No. of Indian automobile manufacturing plants & $\%$ of Indian automobile manufacturing plants \\
\hline 1 & Maharashtra & 21 & 22.58 \\
\hline 2 & Tamil Nadu & 19 & 20.43 \\
\hline 3 & Karnataka & 9 & 9.68 \\
\hline 4 & Haryana & 8 & 8.60 \\
\hline 5 & Madhya Pradesh & 6 & 6.45 \\
\hline 6 & Rajasthan & 6 & 6.45 \\
\hline 7 & Uttarakhand & 5 & 5.38 \\
\hline 8 & Gujarat & 4 & 4.30 \\
\hline 9 & Uttar Pradesh & 4 & 4.30 \\
\hline 10 & Himachal Pradesh & 3 & 3.23 \\
\hline 11 & Andhra Pradesh & 2 & 2.15 \\
\hline 12 & Punjab & 2 & 2.15 \\
\hline 13 & Telangana & 2 & 2.15 \\
\hline 14 & Jharkhand & 1 & 1.08 \\
\hline 15 & West Bengal & 1 & 1.08 \\
\hline & Total & 93 & 100.00 \\
\hline
\end{tabular}

Fig. 3 shows graphically the state wise distribution of the Indian automobile manufacturing plants. It is very evident from Table 3 and Fig. 3 that the order of the states in descending order of the number of Indian automobile manufacturing plants they have is Maharashtra, Tamil Nadu, Karnataka, Haryana, Madhya Pradesh, Rajasthan, Uttarakhand, Gujarat, Uttar Pradesh, Himachal Pradesh, Andhra Pradesh, Punjab, Telangana, Jharkhand, West Bengal. On one end of the spectrum Maharashtra is the state with maximum Indian automobile manufacturing plants and on the other end of the spectrum West Bengal is the state with the least Indian automobile manufacturing plants.

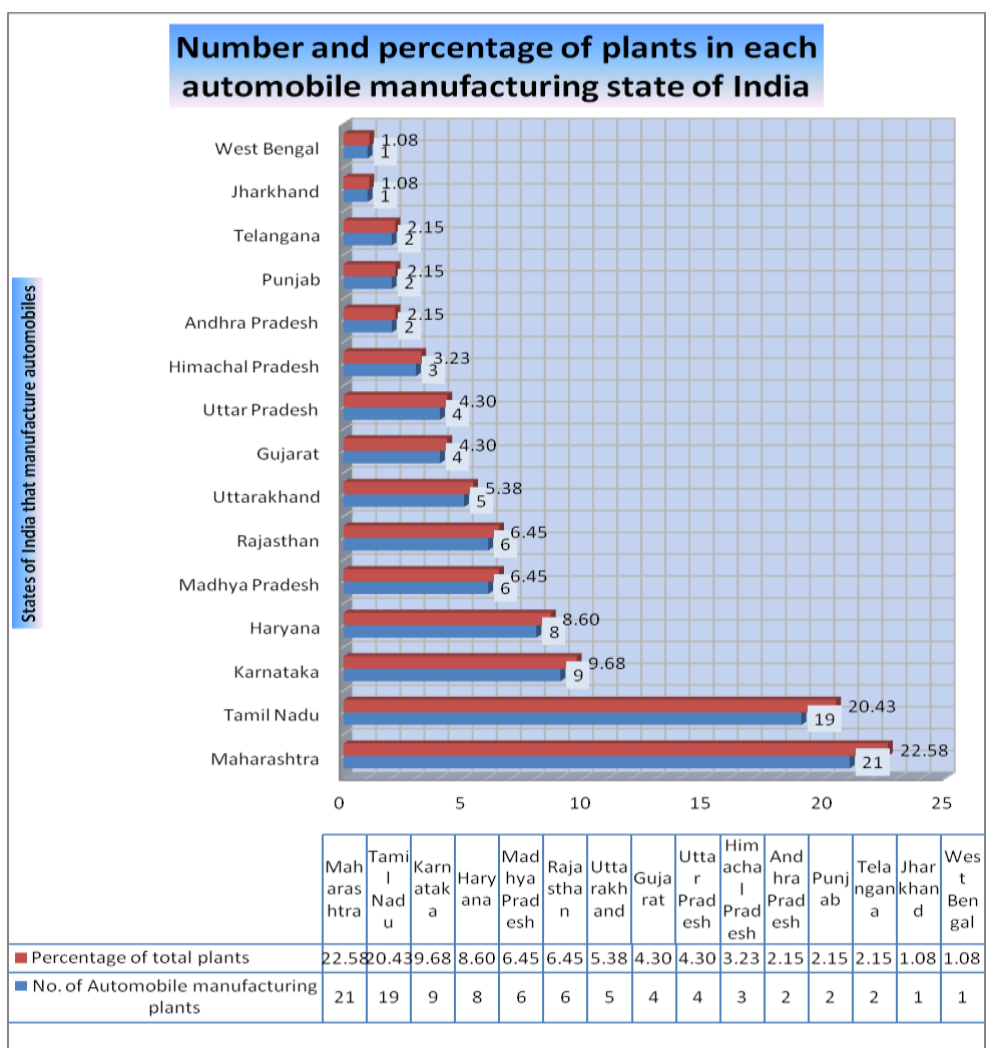

Figure 3. State wise distribution of Indian automobile manufacturing plants 


\section{Location Wise Distribution of Indian Automobile Manufacturing Plants}

There are 53 locations in India spread over 15 states which have Indian automobile manufacturing plants. The number of plants at these locations ranges from a minimum of one at Amb on one end of the spectrum to a maximum of twelve on the other end of the spectrum [1], [2]. Table 4 shows the location wise distribution of the Indian automobile manufacturing plants.

Table 4. Location wise distribution of Indian automobile manufacturing plants

\begin{tabular}{|c|c|c|c|}
\hline Sr. No. & Location & Number of India automobile manufacturing plants & $\%$ of total plants \\
\hline 1 & Amb & 1 & 1.06 \\
\hline 2 & Bhandara & 1 & 1.06 \\
\hline 3 & Bhuj & 1 & 1.06 \\
\hline 4 & Bidadi & 1 & 1.06 \\
\hline 5 & Dharuhera & 1 & 1.06 \\
\hline 6 & Dharwad & 1 & 1.06 \\
\hline 7 & Doddaballapur & 1 & 1.06 \\
\hline 8 & Ennore & 1 & 1.06 \\
\hline 9 & Faridabad & 1 & 1.06 \\
\hline 10 & Halol & 1 & 1.06 \\
\hline 11 & Hindmotor & 1 & 1.06 \\
\hline 12 & Hoshiarpur & 1 & 1.06 \\
\hline 13 & Hoskote & 1 & 1.06 \\
\hline 14 & Jaipur & 1 & 1.06 \\
\hline 15 & Jamshedpur & 1 & 1.06 \\
\hline 16 & Kalladipatti & 1 & 1.06 \\
\hline 17 & Kandivali, Mumbai & 1 & 1.06 \\
\hline 18 & Kodakachani & 1 & 1.06 \\
\hline 19 & Lucknow & 1 & 1.06 \\
\hline 20 & Mandideep & 1 & 1.06 \\
\hline 21 & Maraimalai Nagar & 1 & 1.06 \\
\hline 22 & Mysore & 1 & 1.06 \\
\hline 23 & Nagpur & 1 & 1.06 \\
\hline 24 & Nalagarh & 1 & 1.06 \\
\hline 25 & Nashik & 1 & 1.06 \\
\hline 26 & Nawanshahar & 1 & 1.06 \\
\hline 27 & Neemrana & 1 & 1.06 \\
\hline 28 & Parwanoo & 1 & 1.06 \\
\hline 29 & Ahmednagar & 1 & 1.06 \\
\hline 30 & Ranjangaon & 1 & 1.06 \\
\hline 31 & Satyavedu & 1 & 1.06 \\
\hline 32 & Sri City & 1 & 1.06 \\
\hline 33 & Sriperumbudur & 1 & 1.06 \\
\hline 34 & Surajpur & 1 & 1.06 \\
\hline 35 & Zahirabad & 1 & 1.06 \\
\hline 36 & Alwar & 2 & 2.13 \\
\hline 37 & Aurangabad & 2 & 2.13 \\
\hline 38 & Bangalore & 2 & 2.13 \\
\hline 39 & Greater Noida & 2 & 2.13 \\
\hline 40 & Haridwar & 2 & 2.13 \\
\hline 41 & Kolar & 2 & 2.13 \\
\hline 42 & Manesar & 2 & 2.13 \\
\hline 43 & Sanand & 2 & 2.13 \\
\hline 44 & Talegaon Dabhade & 2 & 2.13 \\
\hline 45 & Tapukara & 2 & 2.13 \\
\hline 46 & Oragadam & 3 & 3.19 \\
\hline 47 & Pantnagar & 3 & 3.19 \\
\hline 48 & Tiruvallur & 3 & 3.19 \\
\hline 49 & Gurgaon & 4 & 4.26 \\
\hline 50 & Hosur & 4 & 4.26 \\
\hline 51 & Chennai & 5 & 5.32 \\
\hline 52 & Pithampur & 5 & 5.32 \\
\hline 53 & Pune & 12 & 12.77 \\
\hline
\end{tabular}


Fig. 4 illustrates graphically the location wise distribution of the various Indian automobile manufacturing plants.

\section{Location wise distribution of various Indian automobile manufacturing plants}

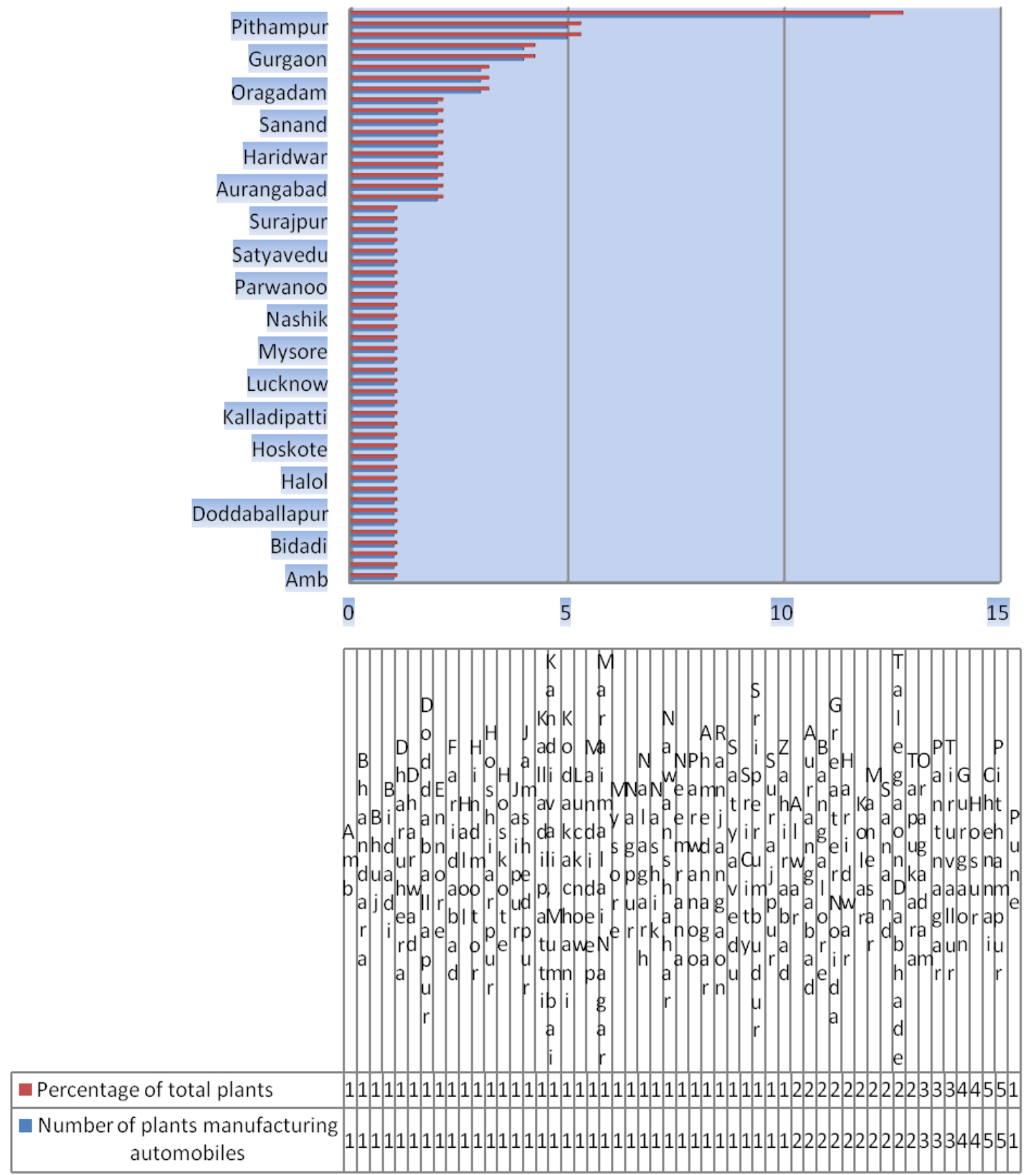

Figure 4. Location wise distribution of various Indian automobile manufacturing plants

\section{Conclusion}

An insight into the Indian automobile manufacturing firms and their plants reveals that there are 58 automobile manufacturing firms in India and in all these 58 firms collectively have 97 plants spread over 15 states of India. Also there are 7 broad categories of automobiles which are manufactured in these plants across 53 locations in India. 


\section{Acknowledgements}

I express my heartfelt thanks to the anonymous reviewers for accepting my views as expressed in the manuscript by me and also for giving good remarks about the quality of work done by me in this manuscript. I would also like to thank Dr. Abdul Razak Honnutagi-Director (Anjuman-I-Islam's Kalsekar Technical Campus, New Panvel) for permitting me to go ahead with my research work from NITIE, Mumbai though our institute was at its formative stage. Also I acknowledge the patience and support of my wife Yasmin Mohd. Asif Gandhi and my children Mohd. Hasan Gandhi and Bnish Gandhi for bearing with me during my long research hours for years. I express my heartfelt thanks to my parents Mr. Indravadan Chimanlal Gandhi and Mrs. Sarmista Indravadan Gandhi for encouraging me and motivating me to complete my research work. I dedicate all my success to them. A big thanks to my guide Dr. Sanjay Sharma for teaching me the importance of original work and for giving me valuable tips on research work from time to time.

\section{References}

[1] www.siamindia.com

[2] https://en.wikipedia.org/wiki/List_of_vehicle_plants_in_India 